\title{
PENERAPAN KESENIAN GURITAN MELALUI PENDEKATAN SCIENTIFIC UNTUK MENINGKATKAN KREATIVITAS MAHASISWA SENDRATASIK UNIVERSITAS PGRI \\ PALEMBANG
}

\author{
Oleh \\ Sherly Marita Utami \\ (Dosen FKIP Program Studi Pendidikan Sendratasik Universitas PGRI Palembang)
}

\begin{abstract}
Abstrak
Penelitian ini diangkat dari permasalahan pembelajaran kesenian guritan yang hanya terfokus pada pemahaman teoritisnya saja, sehingga mahasiswa Universitas PGRI Palembang tidak mendapatkan pemahaman mengenai praktek dalam menuturkan kesenian guritan. Peneliti menerapkan pembelajaran sastra tutur "guritan" melalui pendekatan scientific, bertujuan untuk meningkatkan kreativitas mahasiswa dalam menuturkan kesenian guritan. Dalam penelitian ini, yang menjadi bahan ajar pada pembelajaran kesenian guritan melalui pendekatan scientific adalah kesenian guritan dilihat dari segi konteks dan teks, sehingga mahasiswa dapat mengetahui kesenian guritan dari segi konteks maupun teks. Metode yang digunakan dalam penelitian ini yaitu metode action research, alasan peneliti menggunakan metode ini adalah untuk merancang langkah-langkah pembelajaran yang dapat menjadi acuan dosen dalam menerapkan proses pembelajaran. Subjek pada penelitian ini adalah mahasiswa semeseter 6 di kelas $6 \mathrm{E}$ tahun ajaran 2014 / 2015 Universitas PGRI Palembang.
\end{abstract}

Kata Kunci: Kesenian Guritan, Pendekatan Scientific.

\section{A.PENDAHULUAN}

Guritan adalah salah satu kesenian sastra tutur yang terdapat pada wilayah budaya Besemah yang ada di daerah Provinsi Sumatera Selatan. Sastra tutur guritan disampaikan dengan cara bersenandung. Syair guritan berisi suatu cerita tentang kehidupan petunjuk pengajaran atau pendidikan, cerita kisah potret manusia pada zaman dulu yang dapat diterapkan sebagai panutan di dalam kehidupan masyarakat.

Pada syair guritan terdapat pesan yang akan disampaikan penggurit, yaitu mengenai ; (1) pembelajaran antara manusia dengan tuhannya, (2) pembelajaran antara manusia dengan manusia, sebagai makhluk sosial, dan (3) hubungan antara manusia dengan alam, agar dapat menghargai alam yang ada disekitar kehidupannya.

Guritan baru isi syairnya telah mengikuti perkembangan zaman, sesuai dengan kemampuan penggurit dalam menciptakan syairnya. Tema syair biasanya berkaitan dengan kehidupan masyarakat pada zaman sekarang, seperti menceritakan tentang potret kehidupan manusia pada zaman sekarang, politik atau kampanye, mata pencaharian masyarakat atau kegiatan yang sedang dilakukan masyarakat, seperti pada saat bertani, dan menganyam tikar. Penuturan guritan baru bisa dilakukan dalam waktu singkat, karena penuturan guritan dilakukan pada saat acara-acara yang bersifat umum, seperti syukuran saat panen, acara pernikahan, ketika purnama menerangi jagat Besemah, acara ceremony, dan kampanye.

Pada masyarakat Besemah yang mampu mempelajari kesenian guritanhanyalah senimanseniman tertentu, yang memiliki kemampuan musikal tinggi. Beberapa seniman tersebut, mempelajari kesenian guritan dengan cara autodidak, belajar dari pengalaman yang mereka 
peroleh di masyarakat. Pada zaman dahulu, kesenian ini sangat populer dan mudah diapresiasi,karena seni guritansering mereka dengar, sehingga berada di dalam benak para seniman. Bagi masyarakat yang tidak mampu dalam menuturkan guritan, dalammempelajari kesenian ini memiliki kendala-kendala tertentu, sehingga dibutuhkan suatu cara, agar mereka mudah untuk mempelajarinya.

Salah satu instansi yang mengembangkan materi guritan dalam pembelajarannya, yakni di Universitas PGRI Palembang di Provinsi Sumatera Selatan, Pada kurikulum program studi sendratasik terdapat mata kuliah Sastra Tutur dan salah satu materi yang disampaikan dosen pada saat proses pembelajaran, yakni kesenian guritan. Proses pembelajaran pada mata kuliah sastra tutur khususnya materi guritan, yang diberikan dosen hanya terfokus pada teori. Sedangkan untuk prakteknya, dosen hanya mengajarkan syairnya saja dengan menggunakan bahasa asli Besemah. Akibatnya, mahasiswa sebagai calon guru mendapatkan kesulitan untuk mentransferkan ilmu kesenian guritankepada peserta didiknya karena mahasiswa kurang menguasai tehnik menuturkan syair guritan tersebut.

Dengan diberlakukanya Kurikulum 2013 oleh pemerintah, maka pembelajaran kesenian guritandapat menerapkan model pembelajaran yang menerapkan pendekatan scientific, agar model pembelajaran dapat dikemas lebih menarik dan kekinian. Pendekatan scientific dapat melibatkan mahasiswa secara aktif, dan dapat bereksplorasi dengan keterampilan berpikir kreatif yang dimiliki oleh masing-masing siswa. Menurut Downing (dalam Sani, 2014, hlm. 13) keterampilan berpikir kreatif bertujuan untuk memecahkan sebuah permasalahan, menggunakan ide yang berbeda dengan menggunakan solusi.

Pada proses pembelajaran dengan menggunakan pendekatan scientific, memiliki komponen, antara lain: (1) mengamati, (2) menanya, (3) menalar, (4) mencoba, dan (5) komunikasi atau jejaring (Dyer dalam Sani, 2014, hlm. 53).Pendekatan scientific dipandang sangat tepat karena dalam proses pembelajarannya terkait seni guritan berpijak pada perkembangan teori dan konsep.

Pembelajaran kesenian guritan menggunakan pendekatan scientific, akan diterapkan kepada mahasiswa semester 6 yang bertujuan agar dapat meningkatkan kreativitas mahasiswa, serta model pembelajaran ini, dapat menjadi pedoman mahasiswa untuk menerapkan kepada peserta didiknya.

Pada proses pembelajaran, mahasiswa diberikan kesempatan untuk saling berdiskusi dan akhirnya dapat menuturkan guritan dasar. Pada tahap menyajikan, mahasiswa diberi ruang untuk mengekspresikan penampilannya dalam menuturkan guritanyang sesungguhnya.Proses pembelajaran tersebut sesuai dengan yang dijelaskan di dalam UU Sisdiknas pasal 19 No.1 tentang standar proses yang mengatakan bahwa proses pembelajaran pada satuan pendidikan diselenggarakan secara interaktif, inspiratif, menyenangkan, menantang, memotivasi peserta didik untuk perpartisipasi aktif, serta memberikan ruang yang cukup bagi prakarsadan kemandirian sesuai dengan bakat, minat, dan perkembangan fisik serta psikologis peserta didik. Jadi pembelajaran kesenian guritandengan menggunakan pendekatan scientific, diharapkan 
dapat menuntun mahasiswa untuk belajar dengan aktif, kreatifselama mengikuti proses pembelajaran.

Proses pembelajaran yang mengimplementasikan pendekatan scientific akan menyentuh ranah kognitif, afektif, dan psikomotor. Pada pelaksanaannya, kebanyakan guru masih menggunakan pendekatan bahwa guru sebagai satu-satunya sebagai sumber belajar ( teacher center).

Berdasarkan latar belakang tersebut, maka hal yang akan diangkat peniliti adalah "Bagaimana penerapan pembelajaran guritan melalui pendekatan scientific?".

\section{B.METODE PENELITIAN}

Metode yang digunakan dalam penelitian ini adalah action research. Menurut Alwasilah (2011, hlm. 66) bahwa "Action Research merupakan bagian dari penumbuhan profesionalisme dan merupakan media evaluasi diri (peneliti) dengan melakukan dua hal penting, yaitu: (1) refleksi diri, sehingga semakin memahami apa yang dilakukan selama ini, dan (2) proses perubahan demi perbaikan profesional".Tehnik pengumpulan data yang digunakan adalah observasi dan tes. Dimana peneliti akan mengamati kegiatan mahasiswa selama mengikuti proses pembelajaran, dan memberikan tes berupa penampilan mahasiswa dalam menuturkan guritan dasar.

\section{C.HASIL PENELITIAN DAN PEMBAHASAN}

\section{a)Hasil Penelitian}

Pembelajaran kesenian guritanmelalui pendekatan scientific terdiri dari tiga tahap. Masingmasing tahap memiliki tujuan pembelajarannya tersendiri namun saling berkaitan dan saling mempengaruhi satu sama lainnya. Ketiga tahap memiliki pola pembelajaran dan strategi yang khusus. Namun secara garis besar memiliki konseptual yang sama. Setiap tahapan materi yang disampaikan mahasiswa diharapkan mendapatkan ilmu kesenian guritan dari proses tahap pengenalan dalam proses pembelajaran kesenianguritan (dilakukan pada proses scientific mengamati dan menanya), perolehan mengenai pengetahuan kesenianguritan(dilakukan pada proses scientific menalar), Pendalaman mengenai kesenianguritan berbasis kreativitas (dilakukan pada proses scientific mencoba), dan hasil kesenian guritan berbasis kreativitas yang akan dipresentasikan atau ditampilkan (dilakukan pada proses scientific mengkomunikasikan, menampilkan, atau mempresentasikan).

Konsep dasar dari pembelajaran kesenian guritanmelalui pendekatan scientific ini adalah pembelajaran yang berbasis pada dua hal, yaitu ; 1) hakikat pembelajaran seni musik, dan 2) pembelajaran yang berapresiatif dan kreatif. Dikatakan pembelajaran apresiatif karena dalam berapresiasi, mahasiswa berperan sebagai penikmat atau pengamat yang menyerap atau menghayati suatu karya seni atau gejala keindahan untuk kemudian menanggapi dan menilainya. Pembelajaran kreatif karena melalui pembelajaran tersebut mahasiswa dapat memunculkan kreativitas yang ditujukan dengan kemampuan berpikir lancar, berpikir luwes, dan berpikir orisinil. 
Sedangkan pembelajaran seni musik adalah pembelajaran yang melibatkan mahasiswa secara aktif dalam tiga ranahperkembangan, yaitu kemampuan kognitif, afektif dan psikomotorik.

Penerapan pembelajaran kesenian guritan terdiri dari tiga tahapan materi yang dilakukandalam satu kali pertemuan. Waktu pembelajaran dilakukan selama 100 menit $(2$ x 50 menit). Waktu yang telah ditentukan tidak menutup kemungkinan untuk menambah tatap muka, jika di dalam proses pembelajaran mahasiswa belum mencapai tujuan yang telah ditetapkan. Bagan berikut ini adalah alukoasi penerapan pembelajaran kesenian guritan.

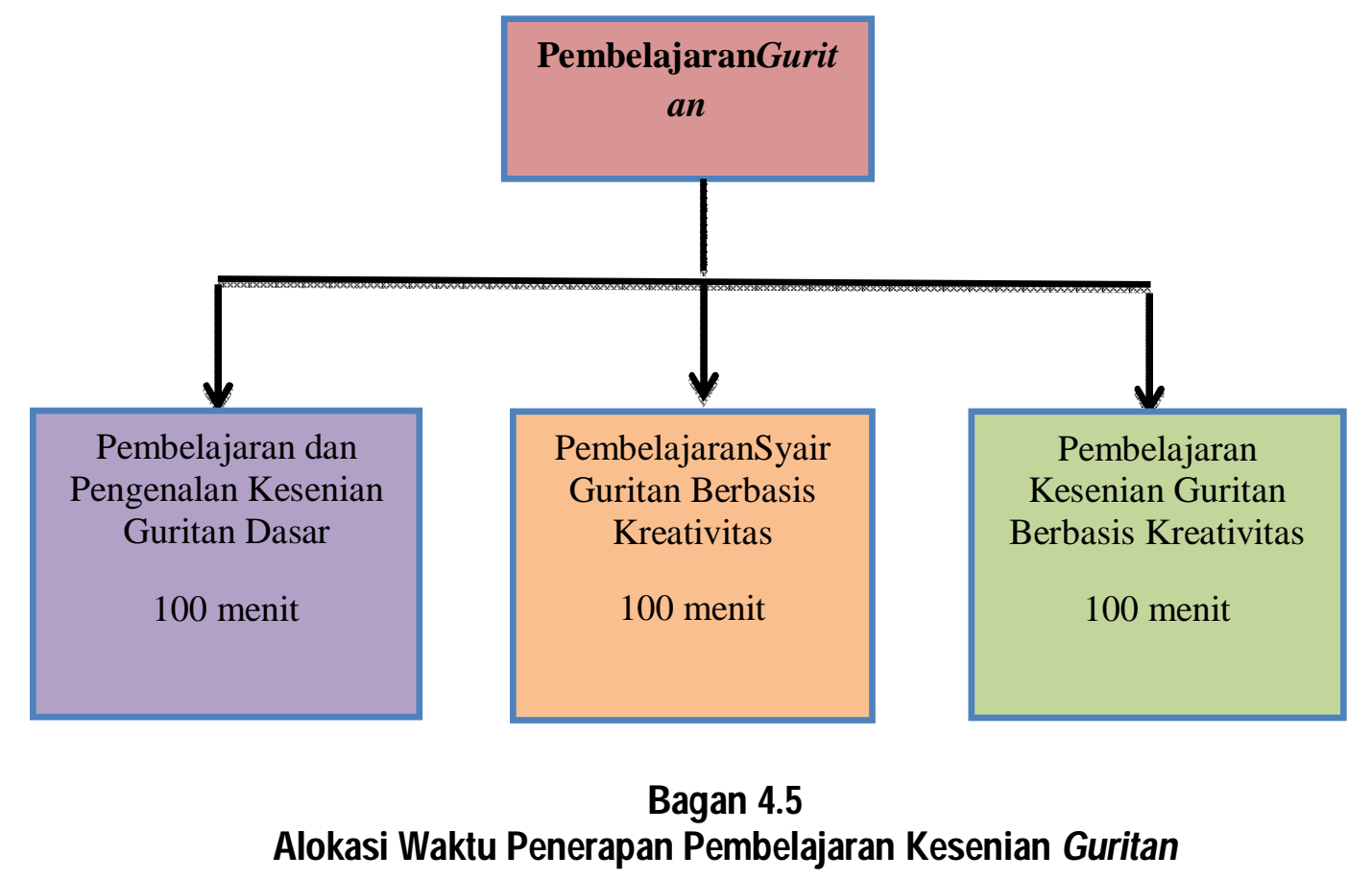

\section{b)Pembahasan}

Dalam penelitian ini, peneliti menerapkan rancangan pembelajaran dan ahapan pembelajaran sesuai dengan mata kuliah Sastra Tutur yaitu materi kesenian guritan dengan standar kompetensi 1. Mengapresiasi kesenian guritan dan 2. Mengekspresikan kesenian guritan. Audio salah satu kesenian guritan merupakan media pembelajaran, diharapkan dapat menstimulus mahasiswa untuk mengetahui dan mengenal kesenian guritan serta dapat menganalisis syair dan melodi kesenian guritan, yang pada akhirnya dapat memunculkan kreativitas pada mahasiswa. Melalui pendekatan scientific, diharapkan pada akhir tahap pembelajaran mahasiswa menampilkan kesenian guritan berbasis kreativitas sebagai wujud hasil karya mahasiswa untuk melatih kemampuan berimajinasi.

a. Pendekatan Pembelajaran

Rancangan pembelajaran kesenian guritan berpedoman dengan menggunakan pendekatan scientific dimana pada proses pembelajaran mahasiswa diharapkan dapat berinteraksi dengan lingkungan disekitarnya. W.Gulo (dalam Siregar, 2010, hlm. 75) mengatakan bahwa pendekatan pembelajaran adalah suatu pandangan dalam mengupayakan cara mahasiswa berinteraksi dengan lingkungannya.Pada materi menciptakan syair guritan mahasiswa diharapkan dapat menciptakan syair guritan dengan berpedoman pada fenomena 
yang terjadi di lingkungan sekitar. Proses pembelajaran dengan menggunakan pendekatan scientific.

1) Tahap observing, mahasiswa mendengarkan salah satu audio kesenian guritan, hal ini agar mahasiswa mengetahui dan mengenal kesenian guritan yang sesungguhnya. Dengan mahasiswa mendengarkan audio kesenian guritan, dapat menambah kepekaan mahasiswa terhadap kesenian guritan. Pada tahapan ini mahasiswa mendengarkan penjelasan dosen.

2) Tahap questioning, Mahasiswa menerapkan wawasan dan pemahaman mahasiswa terhadap kesenian guritan melalui kegiatan tanya jawab. Hal ini memberikan kesempatan pada mahasiswa untuk berpartisipasi aktif pada proses pembelajaran.

3) Tahap associating, pada tahap ini dosen membimbing mahasiswa untuk menalar dalam menganalisi makna syair dan makna melodi berdasrkan kesenian guritan yang didengar pada saat tahap mengamati audio. Pada tahap ini dapat memberikan pengalaman baru mahasiswa dalam menganalisis kesenian guritan, karena sebelumnya mahasiswa belum pernah melakukan proses pembelajaran menganalisis.

4) Tahap experimenting, memberikan kesempatan kepada mahasiswa untuk latihan mencoba menuturkan kesenian guritan yang sesungguhnya sehingga mahasiswa dapat merasakan menuturkan kesenian guritan yang sesungguhnya, mahasiswa mencoba untuk menciptakan syair dan melodi kesenian guritan dengan pengalaman dasar yang telah mereka ketahui mengenai kesenian guritan, sehingga dapat menumbuhkan sikap kreativitas pada diri mahasiswa. Kegiatan menciptakan karya guritan baru merupakan pengalaman baru yang dapat bermanfaat bagi mahasiswa.

5) Tahap communicating, dengan menggunakan pendekatan scientific dapat memberikan kesempatan pada mahasiswa untuk bertindak, memperlihatkan, melibatkan diri, dan membuktikan kreativitasnya dengan menampilkan karya guritan baru masing-masing mahasiswa.

b. Langkah-langkah pembelajaran

Rancangan pembelajaran yang diterapkan mengarah pada tahap kemandirian dan kerjasama antara dosen dan mahasiswa, dimana keterlibatan mahasiswa sangat dibutuhkan dari awal tahapan materi sampai terakhir tahapan materi.Setiap tahapan materi pembelajaran menggunakan tahapan scientific, yaitu mengamati, menanya, menalar, mencoba, dan mengkomunikasikan.

Langkah-langkah pembelajaran guritan yang dirancang dengan menggunakan pendekatan scientific sesuai dengan kriteria pembelajaran dengan menggunakan pendekatan menurut Hosnan (2014, hlm. 37), yaitu (1) materi yang disampaikan pada pembelajaran kesenian guritan berkaitan dengan fenomena yang terjadi di masyarakat, yang terdapat pada syair guritan. Mahasiswa juga diberikan instruksi untuk dapat menciptakan syair guritan berdasarkan fenomena yang terjadi dilingkungan sekitar, baik dari segi alam, dan tingkah laku manusia, (2) penjelasan guru diharapkan dapat merespon aktif kegiatan pembelajaran sehingga proses pembelajaran dapat mencapai tujuan yang diharapkan, (3) mendorong dan menginspirasi mahasiswa untuk berpikir kritis dan menumbuhkan kreativitas mahasiswa dalam menciptakan tuturan guritan baru, 
(4) mendorong mahasiswa untuk dapat memahami makna syair dan melodi kesenian guritan, (5) mengajarkan mahasiswa mengenai fenomena fakta yang terdapat pada syair guritan, (6) dosen menentukan tujuan yang akan dicapai pada saat proses pembelajaran dengan menggunakan langkah-langkah yang menarik pada proses pembelajaran yang dilakukan.

c. Dampak Penerapan Rancangan Pembelajaran

Perubahan perilaku yang terjadi pada mahasiswa merupakan dampak langsung dari proses pembelajaran. Pada pembelajaran ini mahasiswa mengalami pengalaman dalam menganalisis syair mau unsur-unsur musik pada kesenian guritan. Selain itu mahasiswa juga bisa mengetahui bahawa kesenian guritan dapat diterapkan kepada peserta didik melalui pendekatan scientific, sehingga rancangan pembelajaran ini bisa menjadi pedoman untuk mahasiswa dalam menerapkan pembelajaran kesenian guritan kepada peserta didik.

\section{D.SIMPULAN}

Pada proses pembelajaran kesenian guritan melalui pendekatan scientific, yaitu tahap mengamati, menanya, menalar, mencoba, dan mengkomunikaikan. Dimana tahapan scientific ini lebih menekankan pada keaktifan mahasiswa dalam mencari informasi dan memecahkan masalah. Selama proses pembelajaran dapat memberikan kesempatan kepada mahasiswa untuk mengembangkan sensitivitasnya terhadap kesenian guritan melalui indera pendengaran dan juga memberikan pengalaman estetis yang sangat bermanfaat untuk meningkatkan sikap kreativitas mahasiswa.

\section{Daftar Pustaka}

Alwasilah, A Chaedar. (2011). Pokoknya Action Research. Jakarta: PT. Kiblat Buku Utama.

Sani, Ridwan, Abdullah. (2014). Pembelajaran Scientific: Untuk Implementasi Kurikulum 2013. Jakarta: Bumi Aksara.

Himpunan Peraturan Perundang-undangan. Undang-undang Sisdiknas "Sistem Pendidikan Nasional". Bandung: Fokusmedia. 